\title{
Część archaiczna pieśni ojczystej: „wyrafinowany artyzm” a majuskuly jako znaki delimitacji wiersza (źródło versus imitacyjne konstrukcje) ) $^{* *}$
}

DOI: http://dx.doi.org/10.12775/LC.2016.039

\begin{abstract}
Streszczenie: Bogurodzica przekazu kcyńskiego z jej majuskułami jako znakami delimitacji wiersza to podstawa źródłowa zakwestionowania „wyrafinowanego artyzmu” pieśni ojczystej. Jest on nie pierwotnym walorem najstarszego przekazu, lecz wtórnym konstruktem Mediewistów Imitatorów. Przedstawione przez nich wielorakie postacie wierszowego „obrazu” Bogurodzicy prowadzą do podstawowego pytania o tekstowy stan rzeczy: mówimy o sześciu wariantach jednego wiersza czy też o sześciu samoistnych wierszach opatrzonych identycznym tytułem? Majuskuły przekazu kcyńskiego jako znaki delimitacji tekstu dzielonego na wersy pozwalają powiedzieć: Bogurodzica to jedynie „wierszydlo”.
\end{abstract}

Slowa kluczowe: Bogurodzica, majuskuły, „wyrafinowany artyzm”, „wierszydło”

Abstract: Bogurodzica of kcynian form with its majuskules as the signs of a poem delimitation is the base of the trial of questioning "the sophisticated artistry" of the native song. It is not the natural value of the oldest form, but it is the secondary construction made by Medievists Imitators. Various features of the versed "picture" of Bogurodzica, which were presented by them, lead to the basic question about the textual state of affair: we talk about six variants of one poem, or rather about six inde-

* Prof. dr hab., kierownik Zakładu Literatury Staropolskiej, Instytut Literatury Polskiej Uniwersytetu Mikołaja Kopernika. Główne zainteresowania badawcze: nurt religijny literatury staropolskiej, sarmatyzm, teoria i praktyka retoryczna, współczesna humanistyka w interpretacji literatury staropolskiej. E-mail: obremski@umk.pl.

** Tekst ten został przedstawiony podczas konferencji Problemy polskiej interpunkcji - od średniowiecza do współczesności (Warszawa, 16.2.2015; organizator: IBL PAN; pierwotny tytuł: Część archaiczna pieśni ojczystej: „wyrafinowany artyzm" a majuskuły jako znaki delimitacji wiersza). Wywołał skrajnie krytyczne głosy wszystkich trzech dyskutantów. To zrozumiałe, wszak ostatecznie Bogurodzica została przedstawiona jako wierszydło. Z czasem konferencyjny tekst poszerzyłem o nieliczne dopowiedzenia oraz o kilka punktów (one współtworzą drugą część artykułu). Jeden z dyskutantów nie skrywał, że jeśli opublikuję tenże tekst, wówczas napisze - powtarzam dosłownie - „najzjadliwszą polemikę". Pomny owego ostrzeżenia, jednak ogłaszam drukiem tę analizę delimitacyjnej funkcji majuskuł w przekazie kcyńskim. Nawet jeśli moja interpretacja Bogurodzicy jest tylko kuriozalną „interpretacją", to - w moim przekonaniu - warto ją opublikować już tylko nawet jako materię m e to d o l o g i c z n ą. 
pendent poems provided with the identical title? Majuskules of the kcynian form as the signs of the text delimitation, divided into lines, demand the claim: Bogurodzica is the poem without an artistic value.

Key words: Bogurodzica, majuskules, sophisticated artistry, poem without an artistic value

oświęcony Bogurodzicy zeszyt „Pamiętnika Literackiego” (2005, z. 2) już tylko nawet spisem treści zawartych w nim publikacji jednoznacznie dowiódl, że pieśń ojczysta pozostaje wspólną własnością badań Muzykologów oraz Literaturoznawców niejako sprzężonych z Językoznawcami ${ }^{1}$. Zarazem o równorzędnych statusach słów pieśni zapisanych pod nutami (przekaz kcyński) i słów wiersza znanego jako pieśń (przekaz krakowski) doprawdy trudno mówić ${ }^{2}$. Niezależnie od tej różnicy oraz od innych ${ }^{3}$ Literaturoznawcy powinni przyznać, że w przekazie kcyńskim ich wiersz nie jest wypowiedzią samoistną, lecz jednak tylko jakby w przybliżeniu połowiczną (tzn. mówioną) materią archaicznej części pieśni ojczystej ${ }^{4}$. Z formułą „środek przekazu jest przekazem” nie ma dyskusji.

Zważywszy stan badań literaturoznawczych, przyjdzie stwierdzić, że poniekąd bezdyskusyjnie wciąż brzmią te słowa Teresy Michałowskiej:

Ale w gruncie rzeczy wciąż pozostajemy trochę bezradni wobec tajemniczego dzieła, którego wyrafinowany artyzm wznosi początki naszej poezji narodowej do rzędu najwyższych zdobyczy twórczości europejskiego średniowiecza ${ }^{\mathrm{s}}$

Badaczom literatury ów „wyrafinowany artyzm” jawi się głównie jako kunsztowna wersyfikacja - niejako siłą tekstowej rzeczy wywodzona z jednego spośród dwóch naj-

\footnotetext{
1 Ponieważ Muzykolodzy, Literaturoznawcy, Językoznawcy, Mediewiści oraz Imitatorzy należą do społeczności współtworzonych także przez żyjące osoby - przyjmuję pisownię wielkimi literami.

2 "Wiersz organizuje w sposób szczególny dźwiękowe elementy języka. Odbiorca natomiast ma w ręku wyłącznie zapis. [...] Narzuca się pytanie o to, co stanowi właściwy przedmiot zarówno analizy, jak i artystycznego oddziaływania. Na to pytanie wersologia zna dwie odpowiedzi. Jedną sformułował w 1893 r. E. Siviers, znakomity niemiecki fonetyk, twórca szkoły zwanej filologią ucha w przeciwieństwie do tzw. filologii oka, tj. filologii zapisu. »Wiersz [zapis - M. R. M.] to tylko smutny surogat żywego słowa«. Właściwy przekaz poetycki jest wyposażony w żywe wartości foniczne i taki właśnie przekaz powinien być przedmiotem badania". M. R. Mayenowa, Poetyka teoretyczna. Zagadnienia języka, wyd. 2 uzup. i popr., Wrocław 1979, s. 414.

3 "Warto podkreślić, że odmienności dwóch pierwszych strof nie były wielkie; podstawę rozbieżności wspomnianych przekazów stanowiła głównie nieobecność w pierwszym, a obecność w drugim aż 11 dalszych zwrotek". T. Michałowska, Średniowiecze, Warszawa 1995, s. 278.

4 "Jesteśmy [Adam Kulawik] przekonani, że tekst śpiewany posiada własną prozodię, własną organizację prozodyjną, a ściślej mówiąc śpiew uważamy za odrębną formację prozodyjną tekstu, zależną od odmiennego w dużym stopniu zespołu czynników prozodyjnych, występujących w śpiewie i tworzących nowe między sobą relacje: akcent poddany jest regułom muzyki, a więc może być i bywa zawieszany w swojej funkcji systemowej, jaką znamy z prozy (mamy na myśli transakcentacje muzyczne), intonację zastępuje melodia, której przebieg nie ma nic wspólnego z zależnością kadencji od antykadencji, a przebieg melodii określony jest unormowanymi co do wysokości tonami (obowiązuje skala tonów). Wystąpić może niefonologiczny iloczas, który nie ma nic wspólnego z opozycją sylaby krótkiej i długiej". A. Kulawik, Teoria wiersza, wyd. 2 - poprawione i uzupełnione, Kraków 1995, s. 94-95.

5 T. Michałowska, op. cit., s. 291.
} 
starszych przekazów archaicznej części pieśni ojczystej. Wstępne, a zarazem fundamentalne pytanie brzmi: który spośród nich - kcyński czy krakowski przekaz - należy uznać za podstawę rozpoznawania „wyrafinowanego artyzmu” Bogurodzicy? Jeśli pisarz kcyński był

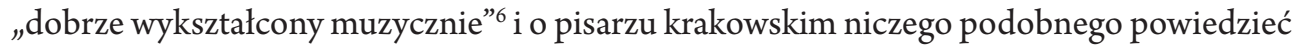
nie można (to, że nic o nim nie wiemy, nie znaczy bynajmniej, że był niemuzykalny!), a zarazem niejako organicznych związków kultury muzycznej i wersyfikacji dowodzić nie ma potrzeby, wówczas wydaje się, że pewniejszą podstawą rozpoznawania kunsztownej sztuki wiersza będzie przekaz kcyński. Zarazem to w przekazie krakowskim słowa Bogurodzicy nie są sprzężone z zapisem nutowym, a więc mają samoistną postać znamienną jeśli już nie dla wiersza, to przynajmniej dla prozy zrytmizowanej ${ }^{7}$. Jednak za wskazaniem na przekaz kcyński jako na podstawę źródłową zakwestionowania „wyrafinowanego artyzmu” przemawiają majuskuły jako znaki delimitacji wiersza. W dawnych przekazach co prawda lekceważono różnicę między majuskułami a minuskułami, jednak w obydwu najstarszych przekazach archaicznej części Bogurodzicy to właśnie te pierwsze są tu tymi znakami językowymi, które pozwalają zakwestionować „wyrafinowany artyzm”. Zarazem niepodobna ukrywać, że jako element grafii swoim statusem nie mogą równać się z dźwiękami.

Paradoksalnie: majuskuły w przekazie kcyńskim tekst „prozaiczny” (rozciągnięty od marginesu do marginesu) regularniej dzielą na wersy niż majuskuły przekazu krakowskiego z jego tekstem „wierszowanym”. Innymi słowy, to nie przestrzenne kompozycje obydwu przekazów wskazują na ich większe bądź mniejsze znaczenie dla rozpoznawania „wyrafinowanego artyzmu” archaicznej części Bogurodzicy, lecz liczba majuskuł. W przekazie kcyńskim jest ich o jedną więcej: siedem. To rozstrzyga o tym, że ostatni wers wiersza liczy trzydzieści sylab. Bez owej majuskuły liczyłby sylab aż czterdzieści dwie. Co prawda obydwie liczby sylab w ostatnim wersie archaicznej części pieśni ojczystej przynajmniej teoretycznie dają pogodzić się z asylabizmem znamiennym dla polskiej poezji średniowiecznej (Maria Dłuska: „Składniowo-intonacyjny formant, zamykający wiersz, w epoce asylabizmu nie miał ograniczeń" $\left.{ }^{\prime}\right)$, to jednak liczby sylab w wersach wcześniejszych niż ostatni nakazują przyjąć, że trzydzieści sylab w ostatnim wersie przekazu kcyńskiego jawi się jako wielkość bliższa praktyce asylabizmu9 niż czterdzieści dwie sylaby ostatniego wersu przekazu krakowskiego.

Kiedy już przyjmiemy przekaz kcyński jako ten przynajmniej regularniejszy, staniemy przed następującym problemem: czy 'unaocznić” „wyrafinowany artyzm” Bogurodzicy znaczy 'wykreować go'? Ten jest bowiem wtórnym konstruktem Mediewistów, nie zaś pierwotnym stanem wierszowej rzeczy któregokolwiek z dwóch najstarszych przekazów. Najogólniej problem zawiera się w pytaniu: jak dowodzić kunsztownej wersyfikacji, skoro obydwa najstarsze przekazy zawierają zapisy znamienne nie tyle dla wiersza, ile raczej dla

6 Ibidem, s. 278.

7 Ostatecznie nawet silne zrytmizowanie prozy retorycznej jeszcze nie rozstrzyga o tym, że ta staje się wierszem, o czym pisał już Arystoteles w Retoryce: „Tekst prozy nie powinien mieć metrycznej formy wiersza, ani też nie powinien być pozbawiony rytmu. [...] Granice wszystkim rzeczom wyznacza przecież liczba, a tą liczbą dla formy językowej jest właśnie rytm, podczas gdy miary wierszowe są tylko jego odcinkami. Dlatego proza musi posiadać rytm, nie może natomiast posiadać miar wierszowych, bo zamieni się w poezję. Nie wolno jednak stosować rytmu rygorystycznie, lecz tylko w ograniczonym stopniu". Arystoteles, Retoryka, [w:] idem, Retoryka. Poetyka, tłum., wstęp, komentarz H. Podbielski, Warszawa 1988, s. 254-255.

8 M. Dłuska, Studia z historii i teorii wersyfikacji polskiej, t. 1, Warszawa 1978, s. 158.

9 "Ogólna rozpiętość sylabiczna wierszy w tych trzech utworach [wierszu Złoty, Legendzie o św. Aleksym, Dialogu ze śmiercią] jest od 5 do 11 sylab, wyjątkowo trafia się zgłosek 4 i 12". Ibidem, s. 157. 
prozy - średniowiecznie zrytmizowanej? Tymczasem tak kcyński, jak też krakowski przekaz w publikacjach Mediewistów stawały się doprawdy kunsztownymi formami wersyfikacyjnymi. Poprzestańmy na tych pochodzących z dziesięcioleci po II wojnie światowej (z jedynym wyjątkiem: Józef Birkenmajer i podążająca za nim Maria Dłuska).

Punktem wyjścia niech będzie dwojaka edycja Bogurodzicy z 1962 roku. Zacznijmy od transkrypcji archaicznej części pieśni ojczystej:

Bogurodzica dziewica, Bogiem sławiena Maryja,

U twego syna Gospodzina matko zwolena, Maryja!

Zyszczy nam, spu<ś>ci nam.

Kyrieleison.

Twego dziela Krzciciela, bożycze,

Usłysz głosy, napetń myśli człowiecze.

Słysz modlitwę, jąż nosimy,

A dać raczy, jegoż prosimy:

A na świecie zbożny pobyt,

Po żywocie ra $<j>$ ski przebyt.

Kyrieleison ${ }^{10}$.

Taki podział na trzy strofy przyjęli (z niewielkimi zmianami w zakresie pisowni wielkimi literami oraz interpunkcji) Julian Krzyżanowski jako autor Historii literatury polskiej ${ }^{11}$, Ewa Ostrowska w studium poświęconym artyzmowi Bogurodzicy ${ }^{12}$, Wiesław Wydra i Wojciech Ryszard Rzepka w Chrestomatii staropolskiej ${ }^{13}$ oraz Teresa Michałowska w Średniowieczu ${ }^{14}$. O publikacjach Ewy Ostrowskiej należy dopowiedzieć: trzy strofy z $O$ artyzmie polskich średniowiecznych zabytków językowych (1967) okażą się... dwiema strofami w Lekturach polonistycznych ${ }^{15}$.

Zarazem w edycji Bogurodzicy z 1962 roku znajdziemy inną transkrypcję archaicznej części pieśni ojczystej:

10 Teksty. Opracowania naukowe i źródła przekazów. Transliteracja - transkrypcja, [w:] Bogurodzica, oprac. J. Woronczak, wstęp językoznawczy E. Ostrowska, oprac. muzykologiczne H. Feight, Wrocław-Warszawa-Kraków 1962, s. 96.

11 J. Krzyżanowski, Historia literatury polskiej. Alegoryzm - preromantyzm, Warszawa 1966, s. 54.

12 E. Ostrowska, Bogurodzica, [w:] eadem, O artyzmie polskich średniowiecznych zabytków językowych („Bogurodzica”, „Kazania świętokrzyskie”, „,Posłuchajcie, bracia miła”), „Zeszyty Naukowe UJ”, nr 154, Kraków 1967, s. 7.

13 W. Wydra, W. R. Rzepka, Chrestomatia staropolska. Teksty do roku 1543, Wrocław 1984, s. 235.

14 T. Michałowska, op. cit., s. 281.

15 E. Ostrowska, ,"Bogurodzica", [w:] Lektury polonistyczne. Średniowiecze-renesans-barok, t. 1, red. A. Borowski, J. S. Gruchała, Kraków 1994, s. 7. 


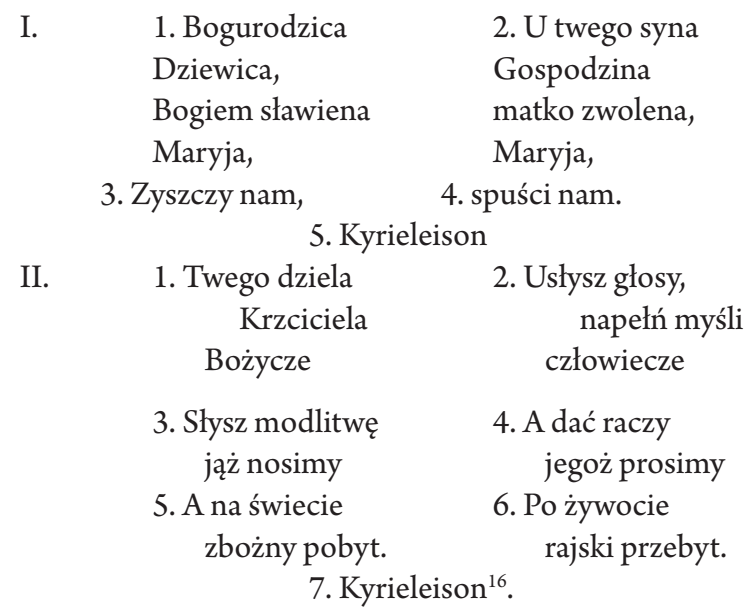

Taką strukturę archaicznej części pieśni ojczystej Jerzy Woronczak wyjaśnił następująco:

Budowa wersyfikacyjna, w każdej strofie inna, wzoruje się na najkunsztowniejszych tropach o cząstkowej budowie sekwencyjnej. Przytaczamy tu tekst według najstarszego przekazu [...]. Od razu rzuca się w oczy nadzwyczajna kunsztowność budowy. Wszystkie semiversiculi, na jakie p o d z i e l i l i ś m y dwie pierwsze strofy pieśni, występują w paralelnych parach jak w sekwencjach. Paralelizm ten dotyczy zarówno podziału na jednakowo długie cząsteczki (trzy razy występuje częsta we wczesnych sekwencjach niezgodność o jedną sylabę), jak i jednakowego układu rymów. $[\ldots]^{17}$

Zachowam zdanie odrębne: Jerzy Woronczak - wbrew jego słowom - nie przytoczył bynajmniej tekstu „według najstarszego przekazu”. Ten bowiem został przez niego przetworzony według wzoru stanowionego „najkunsztowniejszymi tropami o cząstkowej budowie sekwencyjnej”. W drugiej połowie XX stulecia Mediewista, który stał się Imitatorem przekazu kcyńskiego, przesłonił siebie przez niego ożywioną „budową wersyfikacyjną” i dlatego mógł twierdzić, że to nie on, lecz ona „wzoruje się”. Jej antropomorfizacja to chwyt, który może stwarzać (iluzoryczne!) wrażenie, że przekaz kcyński, wszak zachowany w zapisie znamiennym dla prozy (od marginesu do marginesu), to wiersz wspóltworzony przez cztery lub sześć strof (zależnie od tego, czym będzie „Kyrieleison” - wersami bądź strofami). Zarazem w tak sformułowanej, jak w cytacie, charakterystyce budowy pierwszej części Bogurodzicy czasownik „podzieliliśmy” pozwala przyjąć, że Jerzy Woronczak (jako ten, który dokonał podziału wersów) jest współtwórcą - faktycznie kunsztownej - formy stroficznej. Mediewista - powtórzę - stał się Imitatorem przekazu pochodzącego z pierwszego dziesięciolecia XV wieku. Pragnienie unaocznienia artystycznej budowy średniowiecznego wiersza doprowadziło dwudziestowiecznego Mediewistę Imitatora do wierszotwórczej kreacji.

16 J. Woronczak, Wstęp filologiczny, [w:] Bogurodzica, s. 11; w cytacie pomijam liczby sylab, jakimi zostały opatrzone wszystkie "cząsteczki".

17 Ibidem; podkr. wł. - K. O. 
Zasadność najogólniejszej problematyki - 'unaocznić' strukturę archaicznej części Bogurodzicy znaczy “wykreować” „wyrafinowany artyzm” - pozostaje uwarunkowana jeszcze innymi postaciami zapisu. W Historii literatury polskiej Julian Krzyżanowski wyróżnił trzy strofy:

Bogurodzica, Dziewica, Bogiem sławiena Maryja, Twego Syna, Gospodzina, Matko zwolena, Maryja, Ziści nam, spuści nam, Kyrie elejson.

Twego dziela Krzciciela, Bożycze, Usłysz głosy, napełń myśli człowiecze, Słysz modlitwę, jąż [którą] nosimy,

A dać raczy, jegoż [czego] prosimy, A na świecie zbożny pobyt, Po żywocie rajski przebyt, Kyrie elejson. ${ }^{18}$

jednak w Dziejach literatury polskiej przyjął zdecydowanie odmienny zapis, tzn. trzy strofy stały się dwiema:

Bogu rodzica, Dziewica,

Bogiem sławiena Maryja,

Twego syna, gospodzina

Matko zwolena, Maryja.

Zyszczy nam, spuści nam. Kyrie eleison.

Twego dziela krzciciela, Bożycze,

Usłysz głosy, napełń myśli człowiecze!

Słysz modlitwę, jąż nosimy,

A dać raczy, jegoż prosimy,

A na świecie zbożny pobyt,

Po żywocie rajski przebyt! Kyrie eleison ${ }^{19}$.

Tak więc wyłania się wewnętrznie sprzeczny stan tekstowej rzeczy. Liczący trzy strofy zapis pochodzi ze wznowienia Historii literatury polskiej - z 1966 roku. Drugi zapis, dwustrofowy, znajduje się w Dziejach literatury polskiej. Od początków do czasów najnowszych wydanych w 1970 roku. Niejako wbrew tej niewielkiej różnicy liczonej latami publikacji (tylko cztery) stroficzne warianty nakazują czy przynajmniej pozwalają mówić o dwóch różnych tekstach Bogurodzicy: trzy strofy liczące po trzy wersy każda - po czterech latach stały się dwiema strofami o zbliżonej liczbie wersów (pięć i sześć). Nie tylko liczby strof istotnie się różnią - analogicznie rzecz się ma z liczbami wersów: dziewięć wersów zostało przekształconych $\mathrm{w}$ jedenaście. Te może zdawałoby się niewielkie różnice (dwie czy trzy strofy? dziewięć czy jedenaście wersów?) powinny być postrzegane w skali stanowionej wielkością archaicznej części Bogurodzicy. To znaczy poniekąd miniaturową objętością

\footnotetext{
18 J. Krzyżanowski, Historia literatury polskiej. Alegoryzm - preromantyzm, s. 54.

19 Idem, Dzieje literatury polskiej. Od początków do czasów najnowszych, Warszawa 1970, s. 19.
} 
(mierzoną samą liczbą słów - nie skondensowanych nimi znaczeń!). Tak obserwowane różnice liczbowe powinny jednak być postrzegane jako fundamentalne dla „wyrafinowanego artyzmu” wiersza - jeśli bowiem przyjąć, że zapis graficzny jest obrazem mowy wiązanej, wówczas przyjdzie stwierdzić, że Julian Krzyżanowski archaiczną część przekazu kcyńskiego przetworzył w de facto dwie samoistne pieśni ojczyste.

Niepodobna pominąć Marii Dłuskiej, która w Studiach z historii i teorii wersyfikacji polskiej przyjęła („usuwając tylko parę drobnych podziałów”) analizę przeprowadzoną przez Józefa Birkenmajera ${ }^{20}$ i wywiedzioną z niej postać zapisu:

\section{(Periodos I)}

Bogurodzica // Dziewica, // Bogiem sławiena, / Maria //

U Twego Syna, // Gospodzina, // Matko zwolena, / Maria //

Ziści (zyszczy) nam, // spuści nam! //

Kyrie eleison!

(Periodos II, rosnący w liczbę wierszy)

Twego dziela // Krzciciela, // Bożycze, //

Usłysz / głosy, // napełń myśli // człowiecze, //

Słysz modlitwę, // jąż nosimy, //

A dać raczy, // jegoż prosimy, //

A na świecie // zbożny pobyt, //

Po żywocie // rajski przebyt! //

Kyrie eleison! $!^{21}$

Przeniesienie problematyki struktury Bogurodzicy z teorii wiersza do teorii retorycznej co prawda pozwoliło Marii Dłuskiej mówić tylko o jednej strofie, jednak jakby nieuchronnie pojawiły się „Czołowe wiersze trójdzielne względnie czwórdzielne”, „Czołowe wiersze trójdzielne”, „Wiersze dwudzielne” oraz „Refren”. Tym samym okazuje się, że problem struktury zawiera się nie tylko w samej liczbie periodów, lecz także w ich podziałach na mniejsze elementy.

Podobnie jak Jerzy Woronczak i Julian Krzyżanowski, tak też Teresa Michałowska nakazuje przyjąć, że niepodobna mówić o jednej strukturze najstarszej części pieśni ojczystej, przyjąwszy bowiem podział na trzy strofy ${ }^{22}$, zarazem wskazała na to, że:

Pierwsza strofa Bogurodzicy przypomina swą budową „trójkową" zwrotkę łacińskich tropów, co staje się widoczne pod warunkiem dokonania podziału tekstu na rymowane cząstki o ustabilizowanej liczbie sylab (semiversiculi) [...]. Strofa druga odpowiada raczej poszerzonemu wariantowi ostatniej zwrotki łacińskich tropów [...]. Wyodrębnione w ten sposób mikrostrofki wykazują paralelizm właściwy poetyce dojrzałej sekwencji europejskiej (tzw. sekwencji „nowego stylu") $[\ldots]^{23}$.

\footnotetext{
20 „Birkenmajer wyraża pogląd, że nasza pierwotna Bogurodzica nie składa się z dwóch zwrotek, jak dawniej mniemano, ale reprezentuje j e $\mathrm{d} n$ ą, składającą się $\mathrm{z}$ dwóch periodów typową zwrotkę kontakionu $\mathrm{z}$ refrenem Kyrie eleison, również niezmiernie charakterystycznym, tak co do swego rodzaju, jak co do swego rozmieszczenia w pieśni, tego typu bowiem refreny, tak rozmieszczone, były normalną częścią składową omawianych tu strof". M. Dłuska, Studia z historii i teorii wersyfikacji polskiej, t. 1, s. 81, por. s. 82; podkr. wł. - K. O.

21 Ibidem, s. 81-82.

22 T. Michałowska, op. cit., s. 281.

23 Ibidem, s. 288-289.
} 
Pominąwszy symbole cyfrowe i literowe, jakimi Teresa Michałowska opatrzyła dwie pierwsze strofy, można przedstawić je następująco:

Bogurodzica
dziewica
Bogiem sławiena
Maryja,

Twego dziela

Krzciciela, bożycze,

Słysz modlitwę jąż nosimy a dać raczy jegoż prosimy:

\author{
U twego syna \\ Gospodzina \\ matko zwolena \\ Maryja!
}

Zyszczy nam, Spuści nam.

Kyrielejson.

$$
\begin{aligned}
& \text { Usłysz głosy, } \\
& \text { napełń myśli } \\
& \text { człowiecze } \\
& \text { A na świecie } \\
& \text { zbożny pobyt. } \\
& \text { Po żywocie } \\
& \text { rajski przebyt. }
\end{aligned}
$$

Kyrieleison ${ }^{24}$.

Tak więc pięć bądź sześć strof archaicznej części Bogurodzicy zostało podzielonych na mikrostrofki - tych zaś powstało aż dwadzieścia sześć!

Z kolei Andrzej Dąbrówka, chociaż wprost nie zwerbalizował problematyki „wyrafinowanego artyzmu” archaicznej części Bogurodzicy, nieco zwodził czytelników książki wydanej w serii „Mała Historia Literatury Polskiej” - zapowiedziawszy bowiem, że przyjmuje „zapis przejęty z edycji Woronczaka”25, jednak dwakroć znacząco odstąpił od niego. Po pierwsze, ponieważ trzy strofy stają się dwiema:

I.

1. Bogurodzica dziewica, Bogiem sławiena Maryja

2. U twego syna Gospodzina matko zwolena, Maryja.

3. Zyszczy nam,

4. Spuści nam.

5. Kyrielejson

II

1. Twego dziela Krzciciela, bożycze,

2. Usłysz głosy, napełń myśli człowiecze

3. Słysz modlitwę, jąż nosimy,

4. A dać raczy, jegoż prosimy:

5. A na świecie zbożny pobyt,

6. Po żywocie rajski przebyt.

7. Kyrielejson ${ }^{26}$

24 Ibidem, s. 289.

25 A. Dąbrówka, Średniowiecze. Korzenie, Warszawa 2005, s. 155.

26 Ibidem, s. 155-156. 
Po drugie: gdyż trzeci wers pierwszej strofy został podzielony na dwa.

Z tych sześciu przykładów zasadniczo odmiennych przedstawień „wyrafinowanego artyzmu”, tj. kunsztownej sztuki mowy wiązanej, wyłania się „niezgodnie zgodny” stan wersyfikacyjnej rzeczy, który uogólniająco można przedstawić za pomocą tabeli (niejako siłą bibliograficznej rzeczy skażoną lukami):

\begin{tabular}{|c|c|c|c|}
\hline „Imitatorzy”: & $\begin{array}{l}\text { Liczba } \\
\text { strof: }\end{array}$ & $\begin{array}{c}\text { Liczba } \\
\text { wersów: }\end{array}$ & $\begin{array}{c}\text { Liczba } \\
\text { cząstek }^{1} \text { : }\end{array}$ \\
\hline $\begin{array}{l}\text { J. Woronczak I }{ }^{2} \text {; J. Krzyżanowski I }{ }^{3} \text {; E. Ostrowska I }{ }^{4} \text {; } \\
\text { W. Wydra, W. R. Rzepka } ; \text { T. Michałowska I }{ }^{6}\end{array}$ & 3 & 11 & 0 \\
\hline J. Woronczak $\mathrm{II}^{7}$ & $4 / 6^{8}$ & 14 & 26 \\
\hline $\begin{array}{c}\text { J. Krzyżanowski } \mathrm{II}^{9} \text {; Ewa Ostrowska } \mathrm{II}^{10} \text {; Roman } \\
\text { Mazurkiewicz }\end{array}$ & 2 & 11 & 0 \\
\hline M. Dłuska ${ }^{12}$ & 2 & 11 & $24 / 27^{13}$ \\
\hline T. Michałowska II ${ }^{14}$ & 6 & 15 & 26 \\
\hline A. Dąbrówka ${ }^{15}$ & 2 & 12 & 0 \\
\hline
\end{tabular}

${ }^{1}$ Tzn.: elementów mniejszych niż wersy.

2 J. Woronczak, op. cit., s. 96.

3 J. Krzyżanowski, Historia literatury polskiej, s. 54.

${ }^{4}$ E. Ostrowska, ,Bogurodzica”, s. 7; publikacja z 1967 roku (daty roczne pozwalają rozróżnić dwie publikacje o tożsamych tytułach: „,Bogurodzica”).

${ }^{5}$ W. Wydra, W. R. Rzepka, op. cit., s. 235.

${ }^{6}$ T. Michałowska, op. cit., s. 281.

7 J. Woronczak, op. cit., s. 11.

${ }^{8}$ Zależnie od tego, czy dwukrotne „Kyrieleison” potraktujemy jako strofy - na to wskazuje ich samoistny status w przestrzeni wiersza.

9 J. Krzyżanowski, Dzieje literatury polskiej, s. 19.

${ }^{10}$ E. Ostrowska, ,,Bogurodzica”, s. 7 ; publikacja z 1967 roku.

${ }^{11}$ Zob. http://staropolska.pl/sredniowiecze/poezja_religijna/bogurodzica/bogurodzica.html (dostęp: 12.07.2016).

${ }_{12}$ M. Dłuska, Studia z historii i teorii wersyfikacji polskiej, t. 1, s. 81-82.

${ }^{13}$ Zależnie od tego, jak zostanie rozstrzygnięta alternatywa: „[Dwa] Czołowe wiersze trójdzielne względnie czwórdzielne”. W tym miejscu powinienem dopowiedzieć: Maria Dłuska nie zauważa, że drugi wiersz periodu drugiego („Usłysz / głosy, // napełń myśli // człowiecze”) to jeden z dwóch „Czołowych wierszy trójdzielnych” - względnie (!) czwórdzielnych. Przyjąwszy podział czwórdzielny - otrzymamy 27 cząstek.

${ }^{14}$ T. Michałowska, op. cit., s. 289.

15 A. Dąbrówka, Średniowiecze. Korzenie, s. 155-156.

Oczywiście tabelaryczne unaocznienie „wyrafinowanego artyzmu” ma coś z poetyki potocznie werbalizowanej słowami „przeszedł walec i wyrównał”. Rzecz bowiem nie tylko w samych liczbach (np. Maria Dłuska wyróżnia nie strofy, lecz periody, zaś wariantywne liczby cząstek pozostają uwarunkowane tym, że „Czołowe wiersze [pierwszego periodu są] trójdzielne względnie czwórdzielne”; Teresy Michałowskiej trzy strofy są nawet nieporównywalne z tymi trzema wyróżnionymi przez Jerzego Woronczaka), zarazem bowiem tabelaryczne unaocznienie „wyrafinowanego artyzmu” Bogurodzicy współbrzmi z tym, co przeczytamy w Teorii wiersza: 
Proponujemy [Adam Kulawik] następujące dwa sposoby rozumienia terminu wi e rs z:

a) Wiersz jest to sposób prozodyjnego członowania tekstu. Ma ono konsekwentnie arbitralny charakter i tym różni się od prozy, gdzie całkowicie zależy od struktury semantyczno-syntaktycznej tekstu. Arbitralność członowania tekstu realizuje się w postaci wersów, ale także członów wersów i jego cząstek. W wyniku tej arbitralności członowania wersy mogą być pod względem prozodyjnym ściśle ekwiwalentne albo mniej lub bardziej zróżnicowane;

b) Wiersz jest to struktura prozodyjna tekstu wynikająca z jego arbitralnej segmentacji ${ }^{27}$.

Tak w pierwszym, jak też w drugim sposobie rozumienia terminu „wiersz” występują rzeczownik „arbitralność” oraz przymiotnik „arbitralny”. To zaś współbrzmi z tym, jak Mediewiści Imitatorzy unaoczniają „wyrafinowany artyzm” Bogurodzicy.

W takim „niezgodnie zgodnym” stanie tekstowej rzeczy, jaki unaocznia tabelaryczne zestawienie, należy zapytać: czego znakami w przekazie kcyńskim są majuskuły? Podziału części archaicznej na wersy czy podziału na strofy? Za pierwszym, tj. podziałem na wersy, przemawia to, że w nim majuskuły zachowują jednorodną funkcję. Przyjąwszy podział na strofy, przypiszemy majuskułom podwójną funkcję: konstytuują strofy i/lub wersy - zależnie od przyjmowanych graficznych postaci zapisu wiersza.

W moim przekonaniu siedmioma majuskułami części archaicznej („B”, „U”, „S”, „T”, „U”, „S”, „A”) pisarz przekazu kcyńskiego wskazał to, co współcześnie jest zwane delimitacją tekstu wiersza na wersy. Tym samym o jakiejkolwiek strofice tenże przekaz nie pozwala mówić, ponieważ w nim został dokonany jedynie podział na wersy. Dlatego wyróżnianie strof zachowuje coś z analityczno-interpretacyjnego konstruktywizmu. Innymi słowy: skoro pismo sprawia, że dźwięki mowy stają się obrazem, majuskuły przekazu kcyńskiego należy uznać za znaki delimitacji wiersza na wersy. Znaki p i e r w o t n e g o uporządkowania naddanego części archaicznej Bogurodzicy.

W transkrypcji przyjętej za edycją pomnikową z $1962 \mathrm{roku}^{28}$, jednak pominąwszy znaki interpunkcyjne, otrzymamy:

Bogurodzica dziewica Bogiem sławiena Maryja

U twego syna Gospodzina matko zwolena Maryja

Zyszczy nam spu<ś $>$ ci nam kyrieleison

Twego dziela Krzciciela bożycze Usłysz głosy

napetń myśli człowiecze Słysz modlitwę jąż

nosimy $\mathbf{A}$ dać raczy jegoż prosimy a na świecie

zbożny pobyt po żywocie ra<j>ski przebyt kyrieleison.

Pragnę podkreślić: majuskuły w przekazie kcyńskim są przeze mnie postrzegane jako znaki delimitacji wiersza na wersy. To pozwala dojrzeć (powtórzę) p i e r w o t n e uporządkowanie naddane wiersza:

Bogurodzica dziewica Bogiem sławiena Maryja (16)

U twego syna Gospodzina matko zwolena Maryja (17)

Zyszczy nam spu<́s $>$ ci nam kyrieleison (11)

27 A. Kulawik, op. cit., s. 36; podkr. aut.

28 Bogurodzica, s. 96. 
Twego dziela Krzciciela bożycze (10)

Usłysz głosy napetń myśli człowiecze (11)

Słysz modlitwę jąż nosimy (8)

A dać raczy jegoż prosimy a na świecie zbożny pobyt

po żywocie ra $<j>$ ski przebyt kyrieleison (30)

Taki zapis tylko jednej strofy, liczącej siedem wersów, jednakże respektujący delimitacyjną funkcję majuskuł, pozwala przyjąć, że unaoczniające paralelizmy, antytezy czy symetrie wersyfikacyjne „obrazy” kunsztownej sztuki słowa, jaką Mediewiści Imitatorzy znajdują w archaicznej części pieśni ojczystej, to w poważnej części ich własne konstrukcje „wyrafinowanego artyzmu”, dowodzące, jak wielorakie mogą być w tó r n e uporządkowania naddane.

Bogurodzica - a więc również przekaz kcyński z majuskułami jako znakami delimitacji wiersza na wersy - zasadniczo pozostawała słowami pieśni religijnej. Zarazem taki zależny od muzyki (czy przynajmniej z nią współzależny?) wiersz był doprawdy średniowieczny, gdyż jedynie zdaniowy:

- na ogół (wyłączywszy ostatni wers) respektujący zasadę zgodności rozczłonkowania zdaniowego i wersowego

- wiersz bezprzerzutniowy

- wiersz asylabiczny, przy czym o dążności do wyrównania zgłoskowej rozpiętości wersów o tyle trudno mówić, że ostatni wers (liczący aż trzydzieści sylab) to biegunowe przeciwieństwo poprzedzającego go wersu najkrótszego (liczącego tylko osiem sylab)

- rymy w przyjętym wyżej za przekazem kcyńskim zapisie (tj. siedem wersów jednostroficznego wiersza) można najogólniej uznać za nieregularne.

Takie zakwestionowanie statusu Bogurodzicy jako arcydzieła sztuki słowa z jej „wyrafinowanym artyzmem" Mediewistom dlatego o tyle łatwiej powinno przyjść zaakceptować czy przynajmniej rozważyć, że pieśń ojczysta jest wierszem melicznym. To zaś znaczy, że dla słowa podporządkowanego melodii wersyfikacyjne dystynkcje mogą być materią co najwyżej drugorzędną. Zarazem - nawet odrzuciwszy „wyrafinowany artyzm” archaicznej części pieśni ojczystej - może być trudno się oprzeć pokusie, aby liczący aż trzydzieści sylab ostatni wers podzielić na trzy samoistne wersy, co pozwoliłoby znacząco pomniejszyć różnice pomiędzy zgłoskowymi rozpiętościami wersów i tym samym zasadniej mówić o asylabizmie. Tejże pokusie jednak nie należy ulegać - tego wymaga wierność przekazowi kcyńskiemu z jego majuskułami jako znakami delimitacji wiersza na wersy. Unaocznienie sztuki słowa znamiennie średniowiecznej mowy wiązanej nie powinno stać się jej kreowaniem. Badacz Bogurodzicy jako „drugi autor” (Imitator) nie powinien przeważyć nad „pierwszym autorem".

Tak więc przekaz kcyński w jego prymarnej postaci, jeszcze nieprzetworzonej przez Imitatorów, poniekąd wymusza zwerbalizowanie podstawowego pytania o tekstowy stan rzeczy: mówimy o sześciu wariantach jednego wiersza czy też o sześciu samoistnych wierszach? Za drugą odpowiedzią - mówimy o sześciu samoistnych wierszach - przemawia (nie ukrywam, że subiektywny?) ten argument: sześcioraki „wyrafinowany artyzm” Bogurodzicy przekracza granice, w których jeszcze można mówić tylko o wariantach tekstu. Rzecz zawiera się nie tyle w samych wielorakich „obrazach” wiersza (to będzie materią jedynie 
przestrzenną), ile w tym, że każda spośród sześciu „konstrukcji” archaicznej części pieśni ojczystej będzie „programować” sześć samoistnych kompozycji dźwięków wiersza jedynie czytanego. Anonimowy status autora Bogurodzicy i jej dwojakie przekazy (kcyński oraz krakowski) współtworzą taką relację sprzężenia zwrotnego, która sprawia, że spośród dwóch definicji „tekstu" ${ }^{\prime 2}$ ta druga staje się bardziej adekwatna: rzecz bowiem nie tyle w utożsamianiu przekazów z ich zapisami, ile w tym, że przyjmowane przez Mediewistów Imitatorów wielorakie podziały wiersza na wersy wiążą się z odmiennymi językowo-brzmieniowymi warstwami pieśni ojczystej.

Polimorficzność - tak można określić tekstowy status Bogurodzicy konstytuowanej przywołanymi tutaj sześcioma strukturami wersyfikacyjnymi. Mediewiści, wielorako unaoczniwszy „wyrafinowany artyzm” archaicznej części pieśni ojczystej, stali się Imitatorami piętnastowiecznych przekazów. Zarazem ile przestrzennych zapisów - tyleż wierszy! Takie wszak niewiarygodne równanie (sześć konstrukcji wiersza = sześć Bogurodzic) swą zasadność zawiera w tym, czym jest pismo. Najkrótsza odpowiedź brzmi: „sprowadzeniem dynamicznego dźwięku do bezdźwięcznej przestrzeni” ${ }^{30}$. Pełniej: „Zapis [... ] nie składa się jedynie z obrazków, z przedstawień rzeczy, jest bowiem p r z e d s t a w i e n i e m wypowiedzi, słów, które ktoś mówi lub wyobrażamy sobie, że mówi”" ${ }^{1}$. Przejście tekstu od audiosfery do logosfery zawiera w sobie taką możliwość, jaka skrajnie zaktualizowała się w sześciu zasadniczo różnych zapisach Bogurodzicy.

Walter Jackson Ong twierdził:

Pismo lub zapis $[. .$.$] ujmuje słowo w całości, pozwalając na widzialne utrwalenie zanurzonych$ w dźwięku, powikłanych, subtelnych struktur i odniesień, w ich szczególnej złożoności; a to utrwalenie wizualne umożliwia tworzenie jeszcze bardziej subtelnych struktur i odniesień, dalece przekraczając możliwości wypowiedzi oralnej ${ }^{32}$.

Tak właśnie rzecz się ma z piętnastowiecznymi przekazami archaicznej części Bogurodzicy: zawarty $\mathrm{w}$ nich przestrzenny potencjał wiersza ${ }^{33}$ został przez Mediewistów Imitatorów sześciorako zaktualizowany - za przyczyną ich wtórnej wobec przekazu kcyń-

29 „Znaczenia te [tj. definicje „tekstu”] nie tylko nie wyłączają się nawzajem, ale są organicznie związane z procesem powstawania dzieła literackiego i jego utrwalania, a zarazem wyznaczają w sposób jasny i przejrzysty zadania tekstologii [...]. A więc:

1) tekst jest to ostateczny kształt językowy nadany dziełu przez autora w wyniku twórczego procesu i wyrażający tę realizację intencji twórczej, na której osiągnięcie pozwoliły warunki powstawania dzieła i możliwości pisarskie tegoż autora;

2) tekst jest to graficzne utrwalenie wyżej określonego kształtu językowego, czyli po prostu zapis językowobrzmieniowej warstwy utworu [...]". K. Górski, Tekstologia i edytorstwo dzieł literackich, wstęp M. Strzyżewski, Toruń 2011, s. 14.

30 W. J. Ong, Oralność i piśmienność. Słowo poddane technologii, tłum., wstęp J. Japola, Lublin 1992, s. 117.

31 Ibidem, s. 120; podkr. wł. - K. O.

32 Ibidem, s. 121.

33 "[...] warto mimo wszystko skonfrontować się z tym pytaniem: czy, nawiązując do kazuistyki medycznej, nie należałoby uznać za pełnoprawną metodę wersologiczną analizę takiej sytuacji wersyfikacyjnej, gdzie ważne jest właśnie to, że sytuacja taka zdarzyła się tylko raz, ale tym jednokrotnym wystąpieniem pokazała coś naprawdę ważnego? Są w dziejach wiersza, są w dziejach nauki o wierszu takie właśnie momenty: B o g u ro d z ica c zego nie trzeba uzas ad niać; znany liryk Mickiewicza Do B.Z. - przedmiot klęsk naśladowczych tylu poetów romantycznych; tonizm złożony, który Marii Dłuskiej udało się pokazać na przykładzie tylko jednego wiersza - Fryzjerów Tuwima; idiom poetycki Przybosia, o którym Edward Balcerzan bardzo trafnie powiedział, że można go przepisać, ale nie powtórzyć itd... W. Sadowski, Potencjał wersologii (zamiast wstępu), [w:] Potencjał wiersza, red. W. Sadowski, Warszawa 2013, s. 15; podkr. wł. - K. O. 
skiego sztuki wersyfikacji ów przestrzenny potencjał wiersza pozwalał przypisywać sobie „wyrafinowany artyzm”. Nawet trudno uwierzyć, że z pewnością krótki tekst, liczący zaledwie czterdzieści pięć słów, okazuje się (jakby [pre-?] barokowym?) pięknem wielorakim ${ }^{34}$. Nie tyle same przekazy, ile tradycje im przypisywane przez Mediewistów (np. hymny greckie czy lacińskie) zapewne sprzyjają unaocznianiu kunsztownej struktury wersyfikacyjnej, jednak z pewnością nie nakazują zapisu słów pieśni religijnej przetwarzać w tekst znamienny dla kunsztownej sztuki słowa wiązanego strofiką, rymami i rytmem. Co najwyżej przyzwalają. Z czego - trudno się dziwić - korzystają Mediewiści Imitatorzy.

Problem zawiera się zarówno w wielorakich zapisach graficznych Bogurodzicy, jak i w ich statusach: w powojennych edycjach historyczny stan tekstowej rzeczy jawi się jako zdeterminowany kreacjami Mediewistów Imitatorów. Mimowolnie, a nawet wbrew samym sobie: Wszyscy jesteśmy konstruktywistami ${ }^{35}$. To pośrednio potwierdza np. Ewa Ostrowska:

K o m p o z y c j a pierwszej zwrotki Bogurodzicy stała się widoczna dopiero wtedy, gdy zwrotkę dało się rozwiązać usuwając lekcje ingerujące $w$ tekst. Zabieg ten przypominający prace konserwatorskie nad przywróceniem zabytkom plastycznym ich pierwotnej formy wydobywanej spod późniejszych nadbudówek, przemalowań i innych zniekształceń - pozwolił odsłonić kompozycję niezwykłą, prostą i doskonałą ${ }^{36}$.

W kontekście archaicznej części pieśni ojczystej najszersze twierdzenie - Wszyscy jesteśmy konstruktywistami - swoim zakresem najsłabiej obejmie tych, którzy poprzestaną na majuskułach przekazu kcyńskiego jako wyznacznikach podziału jednej strofy na siedem wersów.

Zdzisława Krążyńska i Tomasz Mika, przedstawiwszy „strukturę matematyczną na poziomie liczebności sylab” oraz „Związki odnalezione w rozkładzie wyrazów”, dopowiadają: „Istnienie tych związków, nawet nie uświadomione przez odbiorcę, tworzyło modlitewną aurę" ${ }^{\prime 3}$. Owe matematyczne struktury sylabowo-wyrazowe - niedowierzająco zapytam faktycznie mogłyby tworzyć „modlitewną aurę”? Odpowiedź będzie zakorzeniona tak w materii poznawczej (David Hume: istnieć - znaczy być postrzeganym?), jak też metodologicznej (Wilhelm Dilthey i Verstehen: wczuwanie się), by o historii średniowiecznego Kościoła w Polsce z jego podziałem na elity religijne i lud wiernych już nie wspomnieć (tenże lud jako potencjalny „odbiorca” Bogurodzicy jawi się jako społeczność orantów poważnie ograniczająca recepcję tekstu śpiewanego - byłby świadom jego artystycznej struktury?). W swej istocie eufemistyczne twierdzenie Karola Górskiego „Wiara przeciętnych wiernych nie była tak bardzo pozbawiona czynnika rozumowego, jak by się zdawało, a to dzięki kazaniom i modlitwie myślnej $[\ldots]^{\prime 38}$ nakazuje wątpić, czy matematyczne struktury sylabowo-wyrazowe mogły chociaż współtworzyć „modlitewną aurę” sięgającą szerzej niż ówcześnie elitarne kręgi oraz już dwudziestowieczni Konstruktorzy architektury Bogurodzicy.

\footnotetext{
34 Por. M. Pieczyński, Kirke, Proteusz i Lutnia rozstrojona: o poezji eksperymentalnej późnego baroku w świetle wypowiedzi teoretycznych, Warszawa 2013.

35 E. Domańska, B. Olsen, Wszyscy jesteśmy konstruktywistami, [w:] Rzeczy i ludzie. Humanistyka wobec materialności, red. J. Kowalewski, W. Piasek, M. Śliwa, Olsztyn 2008, s. 83-100.

36 E. Ostrowska, O artyzmie polskich średniowiecznych zabytków językowych, s. 25; podkr. aut.

37 Z. Krążyńska, T. Mika, Architektura „,Bogurodzicy”, ,'Slavia Occidentalis” 1995, s. 75.

38 K. Górski, Zarys dziejów duchowości w Polsce, Kraków 1986, s. 56.
} 
Jakkolwiek to nie zabrzmi, powinno zostać powiedziane: wszystkie analizy, dowodzące „wyrafinowanego artyzmu” archaicznej części Bogurodzicy, pozostają pokazami (w sensie retorycznym - rodzaj zwany wymową demonstratywną) analityczno-interpretacyjnej inwencji Mediewistów Imitatorów. Jeśli wersyfikację uznamy za konstytutywny element wiersza - wówczas należy dopowiedzieć: ile zapisów graficznych najstarszej części pieśni ojczystej, tyle pieśni ojczystych. Kunsztowne analizy „wyrafinowanego artyzmu” archaicznej części Bogurodzicy, sprzężone ze sztuką analizy oraz interpretacji, zostają zwieńczone multiplikacją pieśni ojczystej.

Jedynie hipotetyczne wyjaśnienie konstruktywistycznych nadinterpretacji wiersza po prostu asylabicznego, jakimi pozostają kunsztowne unaocznienia struktury archaicznej części Bogurodzicy, zawiera się w tym, że jej Badacze dwakroć najwyższy status (historyczny oraz religijny) mniej lub bardziej świadomie przenoszą w (przynajmniej współcześnie) samoistny wymiar estetyczny. Innymi słowy: dawność i pobożność pieśni współtworzą sprzężenie zwrotne o wyjątkowej mocy perswazyjnej, toteż poprowadziły do odnajdywania w najstarszej części pieśni ojczystej takiej kunsztownej sztuki słowa, jaka nie była jej dana. Filologicznie bezdyskusyjna formuła ad fontes (tu znaczy: do przekazu kcyńskiego) nakazuje „wyrafinowany artyzm” archaicznej części pieśni ojczystej uznać za mediewistyczną poezję kunsztowną tworzoną przez Imitatorów, nie zaś przez autora słów zachowanych w przekazie kcyńskim. Taki stan tekstowej rzeczy współbrzmi ze słowami Andrzeja Dąbrówki: „To, co dociera do nas jako utwór, dzieło poddawane obserwacji, jest $[\ldots] \mathrm{w}$ istocie płynnym wynikiem przetwarzania danych, raczej ciekłym stopem $\mathrm{w}$ formie niż gotowym odlewem, i to badacz tę formę musi podstawić, aby uzyskać jakiś odlew"39. Majuskuły przekazu kcyńskiego jako źródłowe zakwestionowanie „wyrafinowanego artyzmu” archaicznej części Bogurodzicy pozwalają ów konstruktywistyczny determinizm zminimalizować...

Inne niż podyktowane majuskułami przekazu kcyńskiego podziały archaicznej części pieśni ojczystej na strofy, wersy, semiwersy to niejako nałożone na źródłowy zapis konstrukcje: wtórne uporządkowanie - naddane dziełu literackiemu już przez Mediewistów Imitatorów. Trudno tu powstrzymać się przed przywołaniem Williama Ockhama i jego brzytwy - nie należy mnożyć bytów bez potrzeby...

Pokonferencyjne dopowiedzenia (por. przyp. 1).

1. Ta może nawet szokująca wymowa analizy delimitacyjnej funkcji majuskuł w przekazie kcyńskim - Bogurodzica jawi się bowiem jedynie jako „wierszydło” - jest uwarunkowana wiernością bezdyskusyjnemu nakazowi ad fontes. Tamże, w obydwu najstarszych przekazach, majuskuły pozostają tym, czego niepodobna ignorować. Jeśli przyjąć, że pełnią funkcję delimitacyjną (jakaż inna mogłaby być im dana?), wówczas „wyrafinowany artyzm” może być już tylko tekstową iluzją.

2. Bogurodzica - integralna jako utwór śpiewany - w praktyce badawczej nieuchronnie staje się rozdwojona: melodia Muzykologów versus wiersz Literaturoznawców (niejako zadłużonych u Historyków Języka Polskiego). Zachowanie oryginalnej integralności pieśni jest dwakroć daremnym dążeniem, ponieważ wiersz i melodia w poważnym zakresie

39 A. Dąbrówka, Konstruktywizm w badaniach literatury dawnej, „Nauka” 2009, nr 3, s. 134. 
wciąż współtworzą relację znaną jako ignotum per ignotum, zaś warsztaty Muzykologów i Literaturoznawców pozostają co najwyżej umiarkowanie zintegrowane:

Z centonicznej kwalifikacji melodii Bogurodzicy wynika więc doraźny program jej szczegółowego poznania, realizowanego dotychczas wybiórczo, przypadkowo. Obejmuje on deskrypcję owego porządku centonicznego może nawet i w korespondencji z warstwą słowną utworu, wyczerpującą identyfikację wszystkich owych czterech segmentów [krótkich fraz] i poszukiwanie takiej właśnie struktury w szerokim zakresie - ale tylko - centonicznych wzorów meliki średniowiecznej ${ }^{40}$.

Wyróżnione rozstrzeleniem słowa Muzykologa nie pozostawiają złudzeń: integralność pieśni ojczystej może być dana wyłącznie jej twórcy/twórcom, wykonawcy/wykonawcom oraz słuchaczowi/słuchaczom. W de facto dwakroć samoistnych badaniach melodii oraz słów owa integralność tymczasem wciąż należy do stanu metodologicznej powinności. To może nawet nieuniknione następstwo przejścia od kontemplacji dźwięków (śpiewanych bądź recytowanych) czy słów (tekstu pisanego) do analizy oraz interpretacji. Toteż Literaturoznawca na ogół jedynie może czytać Bogurodzicę, o której wie, że prymarnie była i dalej będzie śpiewana (zawarte w słowach „na ogól” zastrzeżenie pozostaje uwarunkowane tym, jak spójny jest dwojaki, muzykologiczny i językowy, wywód Andrzeja Dąbrówki ${ }^{41}$ ). Jako sztuka słowa pieśń ojczysta poniekąd wymaga jakby przejścia do porządku nad tym, że jej dźwięki jedynie mówione są niczym „kikut” pieśni ${ }^{42}$.

3. Andrzej Zybertowicz, przez Autora Konstruktywizmu w badaniach literatury dawnej nazwany ,jednym z pierwszych przeszczepicieli konstruktywizmu w Polsce”, jeszcze pod koniec ostatniego stulecia pisat:

To hipotezy współ/owocują narzędziami, w które, jak w sieci, pewne rodzaje informacji wpadają, a inne nie; narzędzia przykrawają dane, dane produkowane wedle kulturowo kalibrowanych narzędzi. [...] Dane są wytworem uregulowanych kulturowo działań społecznych tak samo jak hipotezy. Samo rozróżnienie „danych” i „hipotez” jest wytworem społecznym i jest sankcjonowane przez wyobrażenia i działania kulturowo uwarunkowane - w szczególności przez zasady panujące w subkulturach nauki ${ }^{43}$.

Jak te słowa mają się do Bogurodzicy? „Wyrafinowany artyzm” współ/owocuje takimi narzędziami, jak rymy, rytmy, paralelizmy oraz związki z kulturą ówczesnej Europy, natomiast w narzędziowe sieci dotąd nie wpadły majuskuły, które pieśń ojczystą czynią znamiennie średniowiecznym wierszydłem. I w subkulturze historii literatury staropolskiej, i w kulturze narodowej (śpiew na polach Grunwaldu ${ }^{44}$, pierwsza drukowana redakcja

40 M. Perz, Polskie „posłowie” do uwag Rudolfa Flotzingera, „Pamiętnik Literacki” 2005, z. 2, s. 11; podkr. wł. - K. O.

41 A. Dąbrówka, Średniowiecze. Korzenie, s. 162-172 (śródrozdziały Muzyka i Melodia).

42 „Tracąc las, wygrywamy wiedzę o nim. W uroczej sprzeczności angielskie słowo oversight („przeoczenie” i jednocześnie "nadzór" - przyp. tł.) znakomicie oddaje dwa sensy zdominowania przez spojrzenie, ponieważ jednocześnie oznacza ono spoglądanie na coś z góry, jak i niezauważanie tego". B. Latour, Nadzieja Pandory. Eseje o rzeczywistości w studiach nad naukq, red. K. Abriszewski, wstęp K. Abriszewski, Toruń 2013, s. 69-70.

43 A. Zybertowicz, Konstruktywizm jako orientacja metodologiczna w badaniach społecznych; cyt. za: A. Dąbrówka, Konstruktywizm w badaniach literatury dawnej, s. 133.

44 Por. K. Obremski, Czy faktycznie pod Grunwaldem śpiewano „Bogurodzicę"? (tymczasem pierwsza recenzja wydawnicza to dyskwalifikacja tegoż tekstu...). 
w Statucie Jana Łaskiego z 1506 roku, polski kult maryjny: od sarmatyzacji katolicyzmu przez „macierzyńską niewolę Maryi” lat kościelnych obchodów tysiąclecia chrztu Polski po współczesną pobożność katolicką) pieśń ojczysta zajmuje miejsce nieprzewyższone, toteż majuskuły jako znaki delimitacji wiersza niejako siłą swej bluźnierczej rzeczy mogą czy nawet powinny pozostawać poniechane, gdyż jako tekstowe „dane” przeczą powszechnie przyjmowanemu kunsztowi słowa i wiary. Zignorowanie majuskuł to warunek konieczny ocalenia „wyrafinowanego artyzmu”.

4. Autor Konstruktywizmu w badaniach literatury dawnej stwierdza:

Sam zaś zapis, który do nas po długim czasie dociera, jest najczęściej zaledwie ułamkowym śladem rozległych i długotrwałych praktyk wykonawczych, a kształt zapisu rzadko odpowiada oryginałowi, zazwyczaj jest to nowożytna konstrukcja, wypracowana przez pokolenia filologów: „jesteśmy ich spadkobiercami, ale i zakładnikami” ${ }^{45}$.

Niezależnie od tego, czy w ogóle jest możliwe definitywne sformułowanie odpowiedzi na pytanie o czas powstania Bogurodzicy ${ }^{46}$, można czy nawet należy przyjąć, że dwa najstarsze przekazy pieśni ojczystej to owe „ślady rozległych i długotrwałych praktyk wykonawczych”, zaś wielorakie ksztalty zapisu (unaoczniające [rzekomy] „wyrafinowany artyzm”) pozostają kunsztownymi konstrukcjami przynajmniej sześciokrotnie multiplikowanego wiersza (nie mogę wykluczyć, że mojej uwadze uszły jeszcze inne zapisy niż te wskazane w tabeli).

5. Problem bowiem zawiera się w tym, że „wyrafinowany artyzm” archaicznej części pieśni ojczystej (rymy, rytmy, paralelizmy) jest jakby „wydobywany z głębi” dwóch najstarszych przekazów (który starszy? - tej materii jakkolwiek nie podejmuję), natomiast „leżące na powierzchni” owych przekazów majuskuły pozostają niedostrzegane jako znaki delimitacji wiersza. One jednak są faktem językowym, z którym niepodobna dyskutować. Toteż należy zapytać o ich funkcję wierszotwórczą... Znamienne [i o ile dobrze pamiętam]: w obydwu konferencyjnych wystąpieniach, poświęconych średniowiecznej interpunkcji (por. przyp. 1.) Referenci poprzestali na analizach tych znaków, które pojawiały się na końcach zdań bądź na marginaliach. Tymczasem także majuskuły były znakami delimitacji tekstu - Bogurodzicę podzieliły na wersy przeczące „wyrafinowanemu artyzmowi”.

6. Wierszotwórcza moc zapisu Bogurodzicy (sześć struktur wierszowych = sześć pieśni ojczystych) posiada wymowną analogię:

czeski hymn [Svatý Václave] ma odmienną strukturę niż Bogurodzica. Jednak i tutaj, g d y b y śmy dwie pierwsze strofyzapisali nie tak, jak robiono to dotychczas: [...]-ale łącznie, wydłużając wersy,otrzymalibyśmy coś zupełnie

45 A. Dąbrówka, Konstruktywizm w badaniach literatury dawnej, s. 140.

46 Znamienna ewolucja coraz późniejszego datowania: od stanowiska Ewy Ostrowskiej (O artyzmie polskich średniowiecznych zabytków językowych, Kraków 1967) przez Stanisława Urbańczyka („Bogurodzica”. Problemy czasu powstania i tła kulturowego, "Pamiętnik Literacki” 1978, z. 1) i Jerzego Pikulika (Co melodia "Bogurodzicy” mówi nam o czasie powstania pieśni, „Pamiętnik Literacki” 2005, z. 2) do Rudolfa Flotzigera: „[...] powstanie pieśni należałoby datować na schyłek XIV w. i umiejscowić na obszarze Polski południowo-wschodniej, przy czym żywiołowi czeskiemu przypadłaby rola pośrednicząca” (R. Flotzinger, Jeszcze o kwestii „Bogurodzicy”, przeł. A. Gorzkowski, „Pamiętnik Literacki” 2005, z. 2, s. 10). Nie miejsce tu, by jakkolwiek szerzej niż jedynie sygnalnie podjąć wciąż sporną problematykę czasu powstania Bogurodzicy, na przykład późnośredniowieczną genezę Rudolfa Flotzingera podważa Andrzej Dąbrówka: „Jednakże swoje datowanie na schyłek XIV w. wspiera on przestarzałymi argumentami pozamuzycznymi - błędnym powiązaniem liturgii głagolickiej z bizantyńską". A. Dąbrówka, Średniowiecze. Korzenie, s. 170. 
i n n e g o: [...] Pieśń zapisana w ten sposób staje się bardziej regularna od Bogurodzicy, a więc zgodnie ze wspomnianym kryterium [wiek dzieła jest odwrotnie proporcjonalny do regularności jego budowy formalnej, czyli im bardziej dzieło jest w swej formie regularne, tym jest młodsze, i odwrotnie: im mniej regularne, mniej symetryczne, mniej stroficzne, tym jest lub może być - starsze (również genetycznie)] mogłaby być nawet młodsza od niej. Pokazuję [Josip Hamm] ten przykład jedynie po to, by uzmysłowić czytelnikom, jak wielkich roszad można dokonywa ćw materiale literatur dawnych, stosując przyjęte uprzednio kryteria, c zas e m nawet poprzez drobne zmiany, ale nie biorąc pod uwagę wszystkich elementów w ich wymiarze strukturalnym, historycznym i socjolingwistycznym $^{47}$.

Jeśli „wielkich roszad można dokonywać w materiale literatur dawnych [...], czasem nawet poprzez drobne zmiany", wówczas jakim słowem bliskoznacznym do „roszada” należy nazwać taki stan rzeczy, w którym mamy sześć zapisów Bogurodzicy? Mniejsza jednak o kreowanie, a raczej multiplikowanie pieśni ojczystej poprzez sześć struktur wierszowych, ważniejsze bowiem co innego: jeśli jako kryterium dawności dzieła przyjmiemy jego nieregularność, wówczas majuskuły pieśni ojczystej w funkcji znaków delimitacji wiersza wskazują na jej archaiczność?

7. Najwyższa ocena Bogurodzicy jako poezji kunsztownej współbrzmi z podziałami wewnętrznymi kultury pisma (rękopis - druk - posttypografia). Nawet jeśli średniowiecze „wytworzyło swoistą równowagę między oralnością a piśmiennością" ${ }^{48}$, to druk z jego „przestrzenią typograficzną” sprzyjał unaocznianiu konstrukcji wiersza, zaś posttypografia niejako staje się zachętą ${ }^{49}$, aby dalej multiplikować najstarsze przekazy pieśni ojczystej ${ }^{50} \ldots$

8. W artykule Konstruktywizm w badaniach literatury dawnej przeczytamy: „[... ] musimy być świadomi, że tożsamość »dzieł sztuki« nie jest obiektywnie dana, lecz podlega definicji uczestników odbioru i transmisji” ${ }^{51}$.

9. Ludwik Fleck napisał: „Ogólny kierunek pracy poznawczej jest taki: jak największy przymus myślowy przy jak najmniejszej samowoli intelektualnej” ${ }^{52}$. $\mathrm{Na}$ czym polegałaby

47 J. Hamm, „Bogurodzica” w perspektywie południowosłowiańskiej, „Pamiętnik Literacki” 2005, z. 2, s. 21; wyjaśnienie w nawiasie kwadratowym: s. 17; podkr. wł. - K. O.

48 J. Le Goff, Problem historii, przeł. A. Gronowska, [w:] P. Rodak, Pismo, ksiażka, lektura. Rozmowy: Le Goff, Chartier, Hébrard, Fabre, Lejeune, przedmowa K. Pomian, Warszawa 2009, s. 53.

49 "Z uwagi na obciążenie przestrzeni wizualnej znaczeniem nałożonym oraz dlatego, że druk decyduje nie tylko o tym, jakich słów mamy użyć, by powstał tekst, lecz także o stosownym usytuowaniu słów na stronie oraz ich wzajemnych relacjach przestrzennych, sama przestrzeń - jak mówimy: „pusta przestrzeń” (white space) - na zadrukowanej stronie zajmuje ważne miejsce, nawiązując do świata nowoczesnego: postmodernistycznego. [...] Przestrzeń typograficzna oddziaływa nie tylko na wyobraźnię naukową i filozoficzną, lecz również na wyobraźnię literacką, ujawniając złożone sposoby obecności przestrzeni typograficznej w psychice". W. J. Ong, op. cit., s. 173.

50 Jeden z przykładów tego, jak wnikliwa może być analiza nawet stosunkowo krótkich tekstów: R. Jakobson, C. Lévi-Strauss, „,Koty" Baudelaire'a, przeł. M. Żmigrodzka, [w:] Sztuka interpretacji, t. 1, wybór, oprac. H. Markiewicz, Wrocław 1971, s. 563-581.

51 A. Dąbrówka, Konstruktywizm w badaniach literatury dawnej, s. 144. W ostatnim akapicie przeczytamy: „Tym sposobem zarysowaliśmy bardzo wstępnie przesłanki konstruktywistycznej metodologii badań artystycznych w epokach przednowoczesnych, pokazując specyfikę tej grupy dyscyplin i ich obiektów - płynnych wydarzeń historycznych, które należy w celu badania skonstruować (wypreparować), a których obserwacja i interpretacja nigdy nie wyczerpuje się w kontemplowaniu artefaktu, lecz musi dążyć do rozpoznania uwarunkowań generatywnych, a w zachowanych artefaktach dostrzegać zastosowane procedury retoryczne, uwzględniać polimorficzność medialną, transformacje gatunkowe, drogi transmisji". Ibidem, s. 153.

52 L. Fleck, Powstanie i rozwój faktu naukowego. Wprowadzenie do nauki o stylu myślowym i kolektywie myślowym, przeł. M. Tuszkiewicz, wstęp Z. Cackowski, Lublin 1986, s. 126. 
zawarta w tym tekście „samowola intelektualna”? Na zmierzeniu się z dotąd niejako wykluczanymi majuskułami przekazu kcyńskiego. Podjąwszy wyzwanie nimi stanowione, doszedłem do zakwestionowania „wyrafinowanego artyzmu” tak samej Bogurodzicy, jak też jej imitacyjnych multiplikacji.

\section{Bibliografia}

Arystoteles, Retoryka, [w:] idem, Retoryka. Poetyka, tłum., wstęp, komentarz H. Podbielski, Warszawa: Państwowe Wydawnictwo Naukowe, 1988.

Bogurodzica, oprac. J. Woronczak, wstęp językoznawczy E. Ostrowska, oprac. muzykologiczne H. Feight, Wrocław-Warszawa- Kraków: Zakład Narodowy im. Ossolińskich. Wyd. PAN, 1962.

Chrestomatia staropolska. Teksty do roku 1543, oprac. W. Wydra, W. R. Rzepka, red. nauk. W. Kuraszkiewicz, Wrocław: Zakład Narodowy im. Ossolińskich - Wydawnictwo, 1984.

Dąbrówka Andrzej, Konstruktywizm w badaniach literatury dawnej, „Nauka” 2009, nr 3.

Dąbrówka Andrzej, Średniowiecze. Korzenie, Warszawa: Wydawnictwo Naukowe PWN, 2005.

Dłuska Maria, Studia z historii i teorii wersyfikacji polskiej, t. 1, Warszawa: Państwowe Wydawnictwo Naukowe, 1978.

Domańska Ewa, Olsen Bjørnar, Wszyscy jesteśmy konstruktywistami, [w: ] Rzeczy i ludzie. Humanistyka wobec materialności, red. J. Kowalewski, W. Piasek, M. Śliwa, Olsztyn: Instytut Filozofii Uniwersytetu Warmińsko-Mazurskiego, 2008.

Fleck Ludwik, Powstanie i rozwój faktu naukowego. Wprowadzenie do nauki o stylu myślowym i kolektywie myślowym, przeł. M. Tuszkiewicz, wstęp Z. Cackowski, Lublin: Wydawnictwo Lubelskie, 1986.

Flotzinger Rudolf, Jeszcze o kwestii „Bogurodzicy”, przel. A. Gorzkowski, „Pamiętnik Literacki” 2005, z. 2 (poświęcony Bogurodzicy numer monograficzny).

Górski Karol, Zarys dziejów duchowości w Polsce, Kraków: „Znak”, 1986.

Górski Konrad, Tekstologia i edytorstwo dzieł literackich, wstęp M. Strzyżewski, Toruń: Wydawnictwo Naukowe UMK, 2011.

Hamm Josip, „Bogurodzica” w perspektywie południowostowiańskiej, „Pamiętnik Literacki” 2005, z. 2.

Jakobson Roman, Lévi-Strauss Claude, „Koty” Baudelaire'a, przeł. M. Żmigrodzka, [w:] Sztuka interpretacji, t. 1, wybór, oprac. H. Markiewicz, Wrocław: Zakład Narodowy im. Ossolińskich, 1971.

Krążyńska Zdzisława, Mika Tomasz, Architektura „Bogurodzicy”, „Slavia Occindentalis” 1995.

Krzyżanowski Julian, Dzieje literatury polskiej. Od początków do czasów najnowszych, Warszawa: Państwowe Wydawnictwo Naukowe, 1970.

Krzyżanowski Julian, Historia literatury polskiej. Alegoryzm - preromantyzm, Warszawa: PIW, 1966.

Kulawik Adam, Teoria wiersza, wyd. 2 - poprawione i uzupełnione, Kraków: Antykwa, 1995.

Latour Bruno, Nadzieja Pandory. Eseje o rzeczywistości w studiach nad nauka, red. K. Abriszewski, wstęp K. Abriszewski, Toruń: Wydawnictwo Naukowe UMK, 2013.

Mayenowa Maria Renata, Poetyka teoretyczna. Zagadnienia języka, wyd. 2 uzup. i popr., Wrocław: Zakład Narodowy im. Ossolińskich, 1979.

Michałowska Teresa, Średniowiecze, Warszawa: Wydawnictwo Naukowe PWN, 1995.

Ong Walter Jackson, Oralność i piśmienność. Stowo poddane technologii, tłum., wstęp J. Japola, Lublin: Redakcja Wydawnictw KUL, 1992. 
Ostrowska Ewa, „Bogurodzica”, [w:] Lektury polonistyczne. Średniowiecze - renesans - barok, t. 1, red. A. Borowski, J. S. Gruchała, Kraków: Towarzystwo Autorów i Wydawców Prac Naukowych UNIVERSITAS, 1994.

Ostrowska Ewa, Bogurodzica, [w:] eadem, O artyzmie polskich średniowiecznych zabytków językowych („Bogurodzica”, „Kazania świętokrzyskie”, „Postuchajcie, bracia mita”), Kraków: „Zeszyty Naukowe UJ", nr 154, 1967.

Perz Mirosław, Polskie „posłowie” do uwag Rudolfa Flotzingera, „Pamiętnik Literacki” 2005, z. 2.

Pieczyński Maciej, Kirke, Proteusz i Lutnia rozstrojona: o poezji eksperymentalnej późnego baro$k u$ świetle wypowiedzi teoretycznych, Warszawa: Stowarzyszenie Pro Cultura Litteraria i Instytut Badań Literackich PAN, 2013.

Potencjat wiersza, red. W. Sadowski, Warszawa: Fundacja Centrum Międzynarodowych Badań Polonistycznych i Instytut Badań Literackich PAN Wydawnictwo, 2013.

Rodak Pawel, Pismo, ksiażka, lektura. Rozmowy: Le Goff, Chartier, Hébrard, Fabre, Lejeune, przedmowa K. Pomian, Warszawa: Wydawnictwa Uniwersytetu Warszawskiego, 2009. 